YEARBOOK

of ANTITRUST

and REGULATORY

STUDIES

www.yars.wz.uw.edu.pl
Peer-reviewed scientific periodical, focusing on legal and economic issues of antitrust and regulation. Creative Commons Attribution-No Derivative Works 3.0 Poland License.

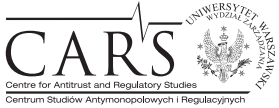

Centre for Antitrust and Regulatory Studies, University of Warsaw, Faculty of Management www.cars.wZ.uw.edu.pl

\title{
How to Facilitate Damage Claims? Private Enforcement of Competition Rules in Croatia - Domestic and EU Law Perspective
}

\author{
by
}

Jasminka Pecotić Kaufman*

\section{CONTENTS}

I. Introduction

II. System of public enforcement in Croatia

III. System of private enforcement in Croatia - right to claim damages for breach of competition law

IV. Competence of commercial courts and breaches of Competition Act

V. Breach of competition rules as prejudicial question and binding effect of the Competition Agency decisions

1. Breach of competition rules as prejudicial question: analysis of possible scenarios

1.1. First scenario

1.2. Second scenario

1.3. Third scenario

1.4. Fourth scenario

2. Case law of Croatian commercial courts - binding effect of Competition Agency decisions

3. Case law of Croatian commercial courts - causal link and use of expert witnesses in follow-on damages actions

VI. Access to evidence in general and legal treatment of access to corporate statements of leniency applicants

1. The right to access the file

2. Access to corporate statements of leniency applicants

VII. Liability for damages for breach of competition rules under Croatian law

1. Legal basis and liability for damages for breach of competition rules

2. Standing - indirect purchasers, passing-on defence and collective legal protection

* Doc. dr. sc. Jasminka Pecotić Kaufman, University of Zagreb. 
2.1. Direct and indirect claimants

2.2. Indirect purchasers as claimants and passing-on defence

2.3. Passing-on defence and exculpation from liability

2.4. Collective legal protection

3. Breach of competition law as harmful act

4. Fault requirement

5. Causal link between the infringement of competition law and the damage

6. Harm as consequence of competition law infringement - types of harm and scope of damages

VIII. Limitation periods and the right to claim damages for infringements of competition law

IX. Conclusion

\section{Abstract}

Ever since the Croatian Competition Agency started functioning in 1997, public enforcement of competition law has been the norm. Civil actions for breaches of competition law have been the exception in Croatia. The existing legislation in the area of competition law makes no effort to incentivise private enforcement. There are no specific rules in the Competition Act 2009 dedicated to civil actions, except a single provision that assigns jurisdiction over damages claims to commercial courts. General tort law is applicable in order to prove damages. A number of issues arise here mostly due to the complexity of competition cases. These issues were described in the European Commission's White Paper on Damages Actions for Breach of EC Antitrust Rules (2008). The level of uncertainty as regards the outcome of the claim is high. It seems that special rules need to be adopted in Croatia in order to improve the position of the injured side. The paper deals with a number of procedural and substantive law issues relevant to the facilitation of civil proceedings for antitrust damages. A domestic law perspective is applied taking into account recent developments in EU competition law and policy.

\section{Résumé}

Depuis 1997 quand l'Agence croate de la concurrence a commencé à fonctionner, l'exécution publique de droit de la concurrence a constitué la norme. Les actions civiles pour violation du droit de la concurrence ont été une exception en Croatie. La législation en vigueur dans le domaine du droit de la concurrence ne succite pas l'exécution par des particuliers. Il n'y a pas de règles spécifiques dans la Loi sur la concurrence de 2009 consacrées aux actions civiles, à l'exception d'une seule disposition qui attribue la compétence à l'égard des demandes d'indemnisation aux tribunaux commerciaux. La responsabilité délictuelle générale est applicable afin de prouver les dommages. Un certain nombre de questions se posent ici principalement en raison de la complexité des affaires de concurrence. Ils ont été décrits dans le 
Livre blanc sur les actions en dommages et intérêts pour infraction aux règles communautaires sur les ententes et les abus de position dominante (2008). Le niveau d'incertitude quant à l'issue de la demande est élevé. Il semble que des règles spéciales doivent être adoptées en Croatie afin d'améliorer la position de la partie lésée. Le document traite sur un certain nombre de questions de droit procédural et droit de fond relatives à la facilitation des procédures civiles en ce qui concerne les dommages suite à des violations du droit de la concurrence. Le point de vue du droit interne est appliqué en tenant compte des développements récents en droit et politique de la concurrence.

Classifications and key words: private enforcement; Croatia; liability for damages; prejudicial question; binding effect; access to evidence; limitation periods; standing; indirect purchasers; passing-on defence; collective protection; harmful act; fault; causal link; types of harm; scope of damages.

\section{Introduction}

The competition process between firms is regulated by certain imperative norms that prohibit competition restricting behaviour. Although the starting point is the constitutional principle of an entrepreneur's and the market's freedom (acting as a foundation of the economic system of the Republic of Croatia $^{1}$ ), this proclaimed freedom is restricted when an undertaking distorts competition ${ }^{2}$. The Croatian Constitution itself narrows down the scope of economic freedom by providing that the state gives all undertakings 'an equal legal position on the market' ${ }^{\prime}$. The freedom of undertakings on the market stretches thus only as far as not to endanger the 'equal legal position' of other market participants. However, the notion of an equal position of firms should not be understood as giving, for instance, all firms an equal amount of market power. Instead, it is a principle ensuring a level playing field on which the creation or strengthening of market power is not prohibited if obtained by competing on the merits ${ }^{4}$. The process of competition must not be obstructed by trying to achieve artificial equality of all operators. The system of market

1 Art, 49 (1) Constitution of the Republic of Croatia (Narodne novine 56/90, 135/97, 113/00, 28/01, 76/10); hereafter, Constitution.

${ }^{2}$ Cf. Art. 2 Competition Act 2009 (Narodne novine 79/09). See also decision of the Croatian Constitutional Court 17/02/11, U-III-4082/2010.

3 Art. 49(2) Constitution.

${ }^{4}$ See judgment of the Croatian Constitutional Court of 29 Septemebr 2010, U-I/769/1998 (Narodne novine 117/10) and judgment of the Croatian Constitutional Court of 22 November 2006, U-I/928/2000 (Narodne novine 135/06). 
economy secures in that sense the freedom to compete, but it also provides its boundaries whereby it prohibits conduct that it deems as restrictive.

Not mentioning any other form of competition restrictions, the Croatian Constitution expressly prohibits the 'abuse of a monopolistic position's. Such provision has not been part of the Constitution before $2001^{6}$, the moment when the original text of the constitutional norm from 1990, which prohibited 'monopoly' as such, was amended'. Despite the earlier constitutional prohibition of a monopoly, the first Croatian Competition Act of 1995 provided detailed rules aimed at regulating 'the abuse of a monopolistic and dominant position'8. Likewise, the Constitutional Court held that 'the earlier constitutional provision on prohibition of monopoly implied no prohibition of monopolies as such, but of certain behaviour of those undertakings which have monopolistic position on the market on the basis of the law, as regulated by the legislator in more details by Competition Act' ${ }^{\prime}$.

\section{System of public enforcement in Croatia}

The Croatian Competition Act provides for two prohibited forms of market conduct: agreements, decisions by associations of undertakings and concerted practice which restrict competition ('prohibited agreements') ${ }^{10}$, and abuse of a dominant position ${ }^{11}$. Restrictive agreements are ex lege null and void ${ }^{12}$. The Competition Agency (hereafter, Agency) has competences as a public law body answering to the Croatian Parliament to investigate and decide on breaches of

5 Art. 49(2) Constitution.

${ }^{6}$ Amendments to the Constitution of the Republic of Croatia, Narodne novine 28/01, Article 16.

7 Art. 49(2) Constitution, Narodne novine 56/90.

8 Competition Act (Narodne novine 48/95, 52/97, 89/98). Although it seems that the notion of 'abuse of monopolistic position' was put in the amended Constitution in 2001, copying the content of the Competition Act 1995 (cf. Art. 13 and 14 Competition Act), it should be noted that the Competition Act 2003 (adopted after Croatia started aligning its domestic legislation with the acquis) no longer refers to a 'monopolistic' position, but only to a 'dominant' position (cf. Art. 15 Competition Act 2003, Narodne novine 122/03) and this is also true for the current Competition Act 2009 (Art. 12).

9 Judgment of the Croatian Constitutional Court of 6 February 2002, U-I/881/1999 (Narodne novine, 48/95, 52/97, 89/98). Confirmed in judgment of the Constitutional Court of 17 September 2003, U-I-1267/2002.

10 Art. 8 Competition Act 2009.

11 Art. 13 Competition Act 2009.

12 Art. 8(4) Competition Act 2009. 
the Competition Act $^{13}$. Firms enjoy court protection before the Administrative Court of the Republic of Crotia (hereafter, Administrative Court) against the decisions of the Agency ${ }^{14}$. Within 30 days from adopting such a decision, a party may start an administrative dispute ('upravni spor') before the Administrative Court. The administrative plea has a suspensive effect - the contested antitrust decision is not enforceable until the adjudicating court rules on the matter ${ }^{15}$. However, a two-tier administrative judicial system was introduced in 2012. Four local administrative courts are competent to hear pleas against antitrust decisions in the first instance ${ }^{16}$ while the High Administrative Court acts in the second instance ${ }^{17}$. The changes introduced as of 1 January 2012 provide for a full-review of administrative decisions of public law bodies in general.

Public enforcement of competition rules is undertaken by the Croatian Competition Agency which initiates proceedings ex officio for the purpose of deciding on prohibited agreements and abuse ${ }^{18}$. Under the Competition Act of 2003, the Agency was empowered to initiate proceedings ex officio but also forced to start proceedings on the basis of a request, except in cases where: the allegedly anticompetitive conduct had a de minimis effect on the market; if it was unimportant for the development and maintenance of effective competition or; if the initiation of antitrust proceedings was not in the public interest ${ }^{19}$. The request to start proceedings could have been submitted by any natural or legal person with a legal or economic interest in the case, by professional or economic interest association, by consumer associations, by the Government of the Republic of Croatia, its central state bodies and local and regional self-government bodies ${ }^{20}$. This has been changed by the Competition Act 2009. The aforementioned groups may still request for the Agency to start proceedings, but the authority is no longer obliged to open proceedings on their initiative ${ }^{21}$. In other words, opening of antitrust proceedings is now within the sole discretion of the Agency.

13 Art. 26 Competition Act 2009.

14 Art. 22(2) Administrative Disputes Act (Narodne novine 20/10), in force as of 1 January 2012.

15 Art. 67(1) and (4) Competition Act 2009.

16 Art. 12(2) Administrative Disputes Act.

17 Art. 12(3) 3 Administrative Disputes Act.

18 Art. 38(1) 1 Competition Act 2009.

19 Art. 41(1) and (2) Competition Act 2003.

20 Art. 41 (4) Competition Act 2003.

21 Art. 37 Competition Act 2009. Also the condition that any legal or natural person has to have legal or economic interest to do so has been deleted. 


\section{System of private enforcement in Croatia - right to claim damages for a breach of competition law}

Private law protection from breaches of the Competition Act is granted in Croatia on the basis of the general tort law right to claim damages and is enforced by commercial courts. Indeed, there is an explicit provision in the Competition Act 2009 that grants jurisdiction for antitrust damages claims to commercial courts ${ }^{22}$. As the only provision in the Competition Act related to private enforcement, general rules of the Obligations Act on torts (non-contractual liability for damages) are applicable for antitrust damage claims $^{23}$.

Two options are available for those that suffered damages due to conduct prohibited by the Competition Act: follow-on actions and stand-alone actions. In the follow-on action scenario public and private enforcement of competition rules is combined. First the Agency adopts a decision on a breach of the Competition Act (public law enforcement) after which the injured entity submits a claim for damages before a local commercial court (private law enforcement). The stand-alone action scenario is a solely private law option where the plaintiff does not rely on an existing decision by the Agency, but leaves it to the court to decide both on the breach of the Competition Act and on the claim for damages.

A question may be asked here as to which scenario is more convenient for the plaintiff for effective compensation. The follow-on option is likely to be far more opportune since the existence of a previous decision of a specialised public-law body will make it possible for to court to avoid getting involved in what is frequently a complex exercise of establishing a competition law infringement ${ }^{24}$. However, if only this option was available, injured entities would only be able to get compensation if the Agency adopted a decision finding a breach of the Competition Act. Since the competition authority is no longer obliged to initiate proceedings upon request, the scope for finding infringements is greatly reduced. In order to make compensation possible in

22 Art. 69(2) Competition Act 2009: 'Competent commercial courts shall decide on compensation of damage caused by infringements of this Act'.

23 Obligations Act, Article 1045 et seq., Narodne novine 35/05, 41/08.

${ }^{24}$ It has been argued that public antitrust enforcement has a strong facilitating effect on private enfrcement since follow-on actions for damages are much easier to bring than stand-alone actions since the earlier public enforcement would have established the existence of a violation and is likely to have generated useful evidence as cause and harm. W. P. J. Wils, 'The Relationship between Public Antitrust Enforcement and Private Actions for Damages' (2009) 32(1) World Competition 3-26, available also at http://papers.ssrn.com/sol3/cf_dev/AbsByAuth. cfm?per_id=456087, p. 19. 
all cases, even if the Agency does not act, it is necessary to secure another option for compensation and that is, the private-private solution (stand-alone actions). As it has already been argued, if private enforcement is primarily seen as an annex or a supplement to public enforcement, the thrust will be to facilitate follow-on actions and to limit claims to strict compensation; if, however, private enforcement was to be seen as a tool to contribute to the enforcement of competition law rules in the public interest, one would have to promote the deterrent effect of private enforcement even beyond mere compensation $^{25}$.

\section{Competence of commercial courts and breaches of the Competition Act}

It is now explicitly clear in Croatia that commercial courts have jurisdiction in damages actions for antitrust infringements ${ }^{26}$. Although this provision is a novelty when compared with the Competition Act 2003, the competence of commercial courts to deal with such disputes had already been clear from the provisions of the Civil Procedure Act regulating jurisdiction of commercial courts, despite the fact that these rules are not entirely in tune with the language of the Competition Act. Pursuant to Article 34b(9) of the Civil Procedure Act, commercial courts are competent to act in civil proceedings in the first instance 'in disputes that arise in connection with acts of unfair competition, monopolistic agreements and violation of equality of the single market of the Republic of Croatia'27. Despite the odd language, it is generally believed that actions for damages for breaches of competition rules are covered by this rule $^{28}$. It should be noted however that none of Croatia's Competition Acts

25 J. Drexl, B. Conde, S. Enchelmaier, M.-O. Mackenrodt, R. Podszun, 'European Commission-White Paper: Damages Actions for Breach of the EC Antitrust Rules - Comments by the Max Planck Institute for Intellectual Property, Competition and Tax Law“ (2008) 39(7) International Review of Intellectual Property and Competition Law 799-811, available also at www. ssrn.com/abstract $=1432330$.

26 Art. 69(2) Competition Act 2009. Cf. Art. 175 Public Procurement Act, Narodne novine 90/11 on the basis of which 'every person who suffered damage for infringements of this Act may claim damages before competent court pursuant to general rules on compensation of damage'.

27 Art. 34b(9), Civil Procedure Act (consolidated text: Narodne novine 148/11). This provision was inserted in 2003 (Narodne novine 117/03). The notion of unfair competition relates to the institution of unfair commercial practices (nepošteno trgovanje) under the Trading Act, such actions are prohibited. See Art. 63 Trading Act (Narodne novine 87/08, 96/08, 116/08,114/11).

28 V. Butorac Malnar, S. Petrović, 'Novo pravno uređenje tržišnog natjecanja', [in:] Zbornik 48. susreta pravnika, Opatija, 12-14 May 2010, Zagreb, 2010, p. 132-133. 
so far mentioned the notion of 'monopolistic agreements'29. It is thus unclear how this notion found its way into the Civil Procedure Act. Not mentioning the abuse of a dominant position, it cannot be even said that the Civil Procedure Act uses a more general language that would cover both types of restrictive practices.

Considering these jurisdictional rules in the context of the views of the European Court of Justice (hereafter, ECJ), whereby in the absence of relevant supranational rules it is up to each Member State to allocate competences for antitrust damages claims ${ }^{30}$, no change of court competences will be needed when Croatia joins the European Union in $2013^{31}$. It seems, nevertheless, that an explicit provision on the competence of commercial courts to hear Article 101 and 102 TFEU cases will have to be inserted into Croatian legislation. In light of the principle of equality invoked by the ECJ, it is only logical that commercial courts should be competent to hear both domestic and EU cases. Moreover, national laws cannot make the enforcement of antitrust damages claims based on domestic rules more advantageous than those based on Articles 101 and 102 TFEU. Finally, in light of the principle of effectiveness, such rules may not make it impossible or excessively cumbersome to exercise EU rights.

\section{Breach of competition rules as prejudicial question and binding effect of decisions of the Competition Agency}

The way domestic procedural law deals with the issue of solving a prejudicial question is of utmost importance within the context of private enforcement of competition rules. It is relevant, in particular, whether the court which has to decide on damages is bound by the decision of the Agency or the appellate (administrative) court finding an infringement. It is also relevant, once Croatia becomes an EU Member State, whether domestic courts will

29 The notion of 'monopolistic' agreements was also unknown to the Competition Act 1995, so the origin of this notion is unclear. Although the Penal Act contained, until its 2011reform (Narodne novine 125/2011), a crime of 'creating a monopolistic position on the market' (Art. 288, Narodne novine 110/97, the provision amended in Narodne novine 129/00), subsequently renamed as 'abuse of monopolistic or dominant position' (Art. 288, Narodne novine 111/03), the notion of 'monopolistic agreement' was not mentioned there.

30 Joined cases C-295/04- C-298/04 Manfredi and others ECR [2006] I-6619, para. 72.

31 Accession Treaty signed on 09/12/11 in Brussels. Council of the EU, 9.12.2011, 18373/11, PRESSE 483, available at http://www.consilium.europa.eu/uedocs/cms_data/docs/pressdata/EN/ genaff/126686.pdf. The ratification process is pending. It is expected that Croatia will become the 28th member of the EU on 01/07/13. See Treaty on Accession of Croatia, OJ [2012] L 112. 
be bound by an infringement decision of the Commission or an National Competition Authority (hereafter, NCA) of another Member State finding a breach of Article 101 or 102 TFEU $^{32}$. Pursuant to Article 16(1) Regulation 1/2003, decisions adopted by the Commission applying Article 101 or 102 TFEU have a binding effect on national courts ${ }^{33}$. Where the Commission has already initiated proceedings but not yet adopted a decision, national courts must avoid delivering rulings that would conflict with a decision contemplated by the Commission. To this effect, domestic courts may find it useful to stay their proceedings. National Competition Authorities are also bound by a Commission decision applying Article 101 or 102 TFEU and cannot take decisions which would run counter thereto ${ }^{34}$. However, the binding effect of decisions applying Article 101 or 102 TFEU adopted by NCAs or national courts is not regulated by Regulation $1 / 2003^{35}$.

Obviously, a binding effect of an earlier antitrust decision or judgment contributes greatly to improving the position of the plaintiff in an antitrust damages action. Normally, it is the plaintiff who bears the burden of proof when it comes to proving that the defendant has breached competition rules. Prejudicial character also helps the civil court to decide more quickly on the scale of damages and contributes to legal certainty by preventing different public decisions being issued as regards the same parties and the same conduct.

In civil antitrust damages actions, the preliminary issue (prejudicial question) for the court to deal with is the question whether an antitrust infringement actually occurred - it is not possible to decide on damages claim without previously deciding on the existence of a prohibited agreement or abuse of dominant position ${ }^{36}$. A prejudicial question is a concrete legal issue being the focus of a different judicial, arbitration or administrative proceedings (which confirms its autonomous legal nature). In this context, it would be the core question of the antitrust proceedings on whether a competition law

32 Cf. Art. 428a(3) Civil Procedure Act: in a retrial, courts must comply with the legal position adopted in the final judgment of the European Court of Human Rights finding a violation of a fundamental right or freedom.

33 Council Regulation (EC) No. 1/2003 of 16/12/02 on the implementation of the rules on competition laid down in Articles 81 and 82 of the Treaty, OJ [2003] L 1/1.

34 Art. 16(2) Regulation 1/2003.

35 The Commission proposed that domestic courts should be bound by final decisions of NCAs finding a violation of Art. 101/102 TFEU as well as by a ruling of a national court which upheld such decision or found an infringement itself, as this would ensure a more homogenouse application of EU law, increase legal certainty and the effectiveness and procedural efficiency of actions for antitrust damages (no duplication); White Paper, p. 6.

${ }^{36}$ For more on prejudicial nature see S. Triva, M. Dika, Građansko parnično procesno pravo, 7th ed., Narodne novine, 2004, p. 96, and M. Dika, “Prethodno pitanje” u parničnom postupku' (2005) 26(1) Zbornik Pravnog fakulteta Sveučilišta u Rijeci 1-51, p. 7. 
infringement took place. This is why a civil court faced with such a question may choose not to deal with it and decide to wait for a decision of a specialised authority competent to decide on that matter as the main question of its own proceedings ${ }^{37}$.

The notion of prejudicial questions relevant for civil proceedings is regulated by the Croatian Civil Procedure Act: 'When for a court decision to be made, it is necessary to previously settle an issue regarding the existence of a right or legal relationship, and no decision on this issue has yet been made by the court or other competent body (prejudicial question), the court may settle this issue on its own, unless otherwise provided for by separate regulations ${ }^{38}$. If the court decides not to deal with the question itself, it will order the stay of its proceedings ${ }^{39}$.

A court faced with a prejudicial question has thus, in principle, two options: to decide that it will tackle the prejudicial question itself or to solve the issue on its own.

If the court decides not to resolve the prejudicial question, it must suspend its proceedings ${ }^{40}$ until a res iudicata becomes available from the competent entity which deals with the issue as the focus of its own proceedings, or until the court finds that there is no longer any reason to wait for such external proceedings to come to a close $\mathrm{e}^{41}$.

Alternatively, a civil court can solve the prejudicial question on its own. The substantive law applicable for finding an antitrust infringement would cover the Competition Act, and related Government regulations as well as, as an auxiliary means of interpretation, EU competition rules on restrictive agreements and the abuse of a dominant position ${ }^{42}$. The burden of proof as regards the actual breach of competition law is on the plaintiff. Problems with obtaining appropriate evidence and difficulties in performing complex economic analyses in order to establish an antirust violation become relevant here. It is not clear under current rules whether a civil court can invite the Agency as amicus curiae to give its opinion on the dispute. Pursuant to the Competition Act 2009, the

37 M. Dika, “Prethodno pitanje” u parničnom postupku', p. 7.

38 Art. 12(1) Civil Procedure Act. The ruling on the prejudicial question shall have legal effect only in the litigation in which this issue was settled, Art. 12(2) Civil Procedure Act.

39 Art. 213(1) Civil Procedure Act.

40 Art. 213(1) Civil Procedure Act in connection with Art. 12(1) Civil Procedure Act.

41 Art. 215(3) Civil Procedure Act.

42 See Art. 70(1) Stabilisation and Association Agreement, Narodne novine - Međunarodni ugovori 14/01. For the implementation of this provision into domestic legislation see Art. 74 Competition Act 2009 and Art. 35 Competition Act 2003. See also decision of the Croatian Constitutional Court in case PZ Auto of 13/02/08, Narodne novine 25/08. More on this issue see in: V. Butorac Malnar, J. Pecotić Kaufman, 'Ocjena koncentracija poduzetnika po kriteriju opadajućeg poslovanja u doba recesije', (2011) 61(4) Zbornik Pravnog fakulteta u Zagrebu 1253-1294, at 1283 et seq. 
Agency must cooperate with competent judicial, regulatory and other bodies in cases related to competition distortions in Croatian territory ${ }^{43}$. However, there is no explicit provision regulating the status of the Agency as amicus curiae before commercial courts deciding on antitrust damages claims.

If a court decided to rule on the existence of a competition law breach as a prejudicial question, and if it found that the defendant infringed competition rules, and if it found liability for damages on the side of the defendant, but the Agency subsequently in its own proceedings decided that no violation occurred, than the defendant may request the court proceedings to be repeated ${ }^{44}$. By contrast, if the court found a breach of competition rules but denied a damages claim since no liability on the side of the defendant could be established, and the Agency subsequently as res iudicata also found an infringement of competition rules (with all public law consequences thereof including a fine), then it would seem that the court proceedings could be repeated only if the decision of the Agency would influence the decision of the court as regards liability. If, on the other hand, the court found, as a prejudicial question, that no infringement took place, then it will refuse the damages claim. However, the plaintiff may request that the court proceedings be repeated if the Agency adopted a decision that established that an infringement did in fact occur ${ }^{45}$.

\section{Breach of competition rules as prejudicial question: analysis of possible scenarios}

The following situations could arise in practice:

- first, the decision of the Agency is both final in administrative proceedings (this is a decision by which proceedings before the public authority are completed $^{46}$ ) and final as res iudicata (this means that no appeal or no administrative dispute can be initiated against $\mathrm{it}^{47}$ ),

43 Art. 66(1) Competition Act 2009. Cf. Art. 90 German Gesetz gegen Wettbewerbsbeschränkungen (GWB) whereby German courts must notify the Bundeskartellamt of any civil actions for antitrust breaches and the NCA joins such proceedings as amicus curiae. Art. 15 Regulation 1/2003 regulates conditions under which the Commission and NCAs may act as amicus curiae before national courts.

44 See Art. 421(9) Civil Procedure Act.

45 Once civil proceedings finish with res iudicata refusing the damages claim, a party may request for the to be repeated if the competent body subsequently settled the prejudicial question by a legally effective decision (res iudicata) on which the court decision is based. Art. 421(9) Civil Procedure Act.

46 S. Triva, M. Dika, Građansko parnično procesno pravo..., p. 352.

47 See Art. 13 General Administrative Proceedure Act (Narodne novine 47/09) in force as of 01 January 2010. 
- second, the decision of the Agency is not yet final in administrative proceedings (proceedings still pending before the Agency),

- third, the decision of the Agency is final in administrative proceedings, but it is not final as res iudicata, since

a) the deadline for lodging an appeal to an administrative court has not yet lapsed, or

b) proceedings before the administrative court are still pending, and

- fourth, the proceedings before the Agency have not been initiated.

\subsection{First scenario}

The Civil Procedure Act is not explicit when it comes to the issue of prejudicial effects of administrative acts. Article 12(1) does not specify what quality must an administrative act ('decision by other competent body') achieve in order to produce prejudicial effects in civil proceedings and in particular, if it is enough that it is final in administrative proceedings or whether it must be res iudicata. It has been argued, however, that it is clear from the Civil Procedure Act that only res iudicata administrative acts have binding effect as regards civil courts deciding on damages ${ }^{48}$. First, proceedings which were stayed because the court decided to await an external decision shall continue when proceedings before another court or competent body are resolved with res iudicat ${ }^{49}$. Second, court proceedings which were closed with res iudicata may be repeated if the decision of the court was founded on a ruling of another court or decision by another body which was reversed, set aside, or vacated as res iudicata, or if the competent body subsequently settled the prejudicial question on which the court decision is based as res iudicata ${ }^{50}$. This position has also been confirmed by Croatian jurisprudence ${ }^{51}$.

48 Interpretation of Art. 12(1) in connection with Art. 215(4) and Art. 421(1)(8) and (9) Civil Procedure Act. M. Dika, “'Prethodno pitanje” u parničnom postupku', p. 10, 11. See also I. Crnić, Parnični postupak and naknada štete - Primjena propisa o parničnom postupku u parnicama za naknadu štete and iz odnosa osiguranja, Organizator 2008, p. 24.

49 Art. 215(4) Civil Procedure Act.

50 Art. 421(1)(8) and (9) Civil Procedure Act. If for the purpose of repeating the proceedings only a res iudicata administrative decision is to be taken into account, it must be concluded, argumento a cohaerentia, that any court ruling in connection with which it is requested that proceedings be repeated must be based only on res iudicata administrative decisions. M. Dika, "'Prethodno pitanje" u parničnom postupku', p. 45.

51 In civil proceedings the court is not authorised to assess the validity of a res iudicata decision adopted in administrative proceedings. Judgment of the High Commercial Court, Pž-904/2009 of 30 July 2009. The court may not resolve as a prejudicial issue dealt with by another competent body in a res iudicata decision. See Judgments of the Supreme Court: Rev-1259/01 of 10 October 2001; Rev-288/03 of 05/05/04; Rev-50/2007-2 of 14 February 2007. In civil proceedings the court is bound by a res iudicata administrative act and by a judgment of 
Although it seems that no jurisprudence of higher instance courts exists relating directly to prejudicial questions in competition law cases, it can be concluded on the basis of the abundant jurisprudence cited above that civil courts are bound by a res iudicata decision of the Agency and by a res iudicata judgment of the Administrative Court as regards a finding of a prohibited agreement or abuse of a dominant position. They are thus not authorised to question the validity of such decisions or judgments. This prevents a situation where civil courts, the Agency, and administrative courts would all take different positions as regards the same legal issue. Importantly, being bound only by res iudicata decisions supports the principle of legal certainty since it prevents unnecessary changes in court rulings due to the fact that administrative acts, which are only final in administrative proceedings but not res iudicata, could be reversed before those administrative courts that exercise control over decisions adopted by the relevant authorities ${ }^{52}$.

It has been argued that courts cannot deal with an issue that has already been resolved as the core matter by another court or competent body because of the ne bis in idem principle. It has also been said that deciding all over again on the same issue would be both against the principle of procedural economy and against the principle of legal certainty, since it could result in contradicting decisions ${ }^{53}$. Mutual confidence in adopted decisions is justified in light of the division of competences principle between courts and specialised public bodies ${ }^{54}$.

\subsection{Second scenario}

If the decision of the Agency is not final in administrative proceedings, the civil court deciding on damages may either rule on the existence of an antitrust infringement ${ }^{55}$, or stay its proceedings and wait until res iudicata is available

the Administrative Court; it is not authorised to question the validity of res iudicata decisions adopted by competent authorities. See judgment of the Supreme Court Rev-639/05 of 16 March 2006 and Revr-127/06 of 09/0506. See also judgment of the Supreme Court in case Rev-358/05 of 18 May 2005.

52 M. Dika, "Prethodno pitanje" u parničnom postupku', p. 46. Dika notes that Croatian case law relates only to prejudicial effect of res iudicata administrative decisions, and that there are no cases where prejudicial effect of administrative decisions final in administrative proceedings was taken into account. However, see infra for case law where prejudicial effect of decisions final in administrative proceedings was accepted by first instance commercial courts (Zračna luka v Croatia Airlines).

53 M. Dika, “Prethodno pitanje” u parničnom postupku', p. 10.

54 M Pavlović, 'Značaj prejudicijelnih pitanja u parnici' (2003) 3(7) Hrvatska pravna revija, p. 83-84.

55 Art. 12(1) Civil Procedure Act. 
or until it decides that there are no longer reasons to wait for the conclusion of external proceedings ${ }^{56}$. Since the Civil Procedure Act offers no guidance on when the court should decide on the prejudicial question on its own and when to stay its proceedings, it seems entirely up to the court which option to choose. However, some commentators quite rightly argue that courts are not in fact left with such wide discretion because they must obey key principles of civil procedure, in particular the principle of autonomy in adjudication and the principle of procedural economy. As a result, a court should without a doubt stay its own proceedings if the prejudicial question is the core issue in pending proceedings before a competent court or body ${ }^{57}$. The rationale here is clear: it would not be opportune to invest into the adjudication of a legal issue if a competent court or body is about to adopt a meritorious decision thereon which could be a valid ground for requesting the civil proceedings (which were not stayed and ended in res iudicata) to be repeated despite the fact that it would have been appropriate to have stayed them ${ }^{58}$. The stay of proceedings in order to await the decision of a competent body is thus opportune in particular in situations where the same issue is the focus of another competent court or state body, as well as in situations where parallel proceedings are not yet pending but they can be initiated ex officio provided that a party which was instructed by the court to request the initiation of such proceedings will be motivated to start such proceedings without delay ${ }^{59}$.

If the court decides to deal with the prejudicial question where no alternative res iudicata decision is available, the legal effect of its ruling on the prejudicial question is limited to its own civil proceedings ${ }^{60}-$ civil courts are thus not bound by an earlier ruling on the same prejudicial question ${ }^{61}$. This applies both to the court that has delivered the actual ruling as well as to other courts ${ }^{62}$. Jurisprudence suggests also that if a judgment in which the court decided on a prejudicial question was rescinded upon appeal, the same court may decide on the prejudicial question differently in the same case ${ }^{63}$.

56 Art. 213(1) and Art. 215(3) Civil Procedure Act.

57 M. Pavlović, 'Značaj prejudicijelnih...', p. 88.

58 Ibidem, p. 89; see Art. 421(1)(6) and (8) Civil Procedure Act.

59 M. Pavlović, 'Značaj prejudicijelnih...', p. 83-84.

60 Art. 12(2) Civil Proceedings Act.

61 Judgment of the Supreme Court Rev 54/93 of 07 October 1993 - IO 1/1996-165. Also see M. Dika, “"Prethodno pitanje” u parničnom postupku', p. 10.

62 I. Grbin, 'Pravomoćnost odluka u parničnom postupku', Godišnjak no. 9/02 - 17. savjetovanje Aktualnosti hrvatskog zakonodavstva i pravne prakse, available at www.vsrh.hr/ CustomPages/Static/HRV/Files/IGrbin-Pravomocnost_odluka.pdf.

63 Judgment of the Supreme Court in case Rev $1 \overline{77} / 82$ of 13/03/84 - PSP 25/185. 


\subsection{Third scenario}

If the decision of the Agency was final in terms of administrative proceedings but not yet res iudicata, the civil court considering a damages claim has the same options as in cases of a decision not final in terms of administrative proceedings. In other words, the court is bound by a final decision of the Agency but only if it is res iudicata ${ }^{64}$. However, the aforementioned arguments still apply, and it is thus most likely that civil proceedings will be stayed in order to await res iudicata.

\subsection{Fourth scenario}

In the absence of antitrust proceedings, a civil court may resolve the prejudicial issue with legal effects limited to the given case ${ }^{65}$. Some authors argue that court proceedings ought to be stopped if the court finds that a party has a legal interest to initiate proceedings before a competent court or body. In such cases, the civil court should instruct that entity to do so before a certain deadline. If such party does not do so, the court should resolve the prejudicial issue on its own $^{66}$. Other commentators note that, if the court decides not to resolve the prejudicial issue, it must instruct the parties to initiate proceedings before another court or competent body or to initiate such a procedure $e x$ officio ${ }^{67}$.

It is questionable however what implications such an approach would have in the context of competition law. Pursuant to the Competition Act 2009, the Agency initiates all proceedings ex officio. Others are merely left with the right to submit a non-binding request for the Agency to act. It is however wholly within the discretion of the competition authority whether to do so. As a rule, the Agency should start proceedings unless the allegedly anticompetitive conduct is de minimis, or if any other conditions for refusal are fulfilled ${ }^{68}$. It is questionable whether a commercial court could request for the Agency to act. There is no explicit provision to this effect in Croatian law.

${ }^{64}$ A civil court may solve the prejudicial issue only if a competent court or body has not yet adopted a decision on that issue; courts are bound by res iudicata administrative decisions. See judgment of High Commercial Court Pž-2871/01 of 03 June 2003. However, see infra some recent jurisprudence of first instance commercial courts accepting as binding for civil courts the decisions of Competition Agency which are only final in administrative proceedings, but no res iudicata is available.

65 Art. 12(1) and (2) Civil Procedure Act.

66 M. Pavlović, 'Značaj prejudicijelnih...', p. 88.

67 M. Dika, "Prethodno pitanje” u parničnom postupku', p. 8.

68 Art. 38(4) and (5) Competition Act 2009. In practice the Agency has great discretion in rejecting such request. 
Under the Competition Act 2009, 'any legal or natural person' may submit 'an initiative' to open up antitrust proceedings. ${ }^{69}$ Courts are public bodies which exercise their judicial authority autonomously and independently, within their competences, as prescribed by law ${ }^{70}$. As state organs they are not, however, separate legal entities.

\section{Jurisprudence of Croatian commercial courts - binding effect of antitrust decisions}

There is a scarcity of commercial courts' jurisprudence in Croatia on disputes related to competition law infringements, and this is an understatement. Since only a small number of commercial court judgments are at all available on-line, searching for relevant rulings is an adventure in itself. It was ultimately possible to identify only a small number of judgments fitting the purpose of this article (most of them not yet final), and hence no wider conclusions can be drawn at this point on jurisprudential trends and focal issues in private enforcement of competition rules in Croatia. Still, scarcity of relevant rulings must be primarily attributed to the lack of plaintiffs lodging antitrust damages claims and not to problems with availability and transparency of Croatian jurisprudence. The identified rulings shed, nevertheless, some light on issues such as: binding effect of antitrust decisions, division of competences between civil courts and the Agency, and the use of expert opinions in follow-on cases.

The only Croatian case with res iudicata is very peculiar and although it was not an action for antitrust damages it seems to give quite a few insights for private enforcement of competition law. While it could be expected that a victim would, on the basis of an antitrust infringement decision finding an abuse $^{71}$, claim antitrust damages before commercial court as a follow-on action, this case followed the opposite scenario. The case concerned a subsidiary of the company that runs Zagreb Airport, which provided catering services to the national air carrier, Croatia Airlines. This company, which was subsequently (while civil actions were pending) found by the Agency to have breached competition rules, sued its 'victim' for the fulfilment of contracts (unilateral increase of prices which were found by the Agency to constitute an abuse of a dominant position). It was precisely the very attempt to judicially enforce the contested conduct that the Agency found to be an abuse. Even more interestingly as far as procedural strategy in concerned, the plaintiff (a firm

\footnotetext{
69 Art. 37 Competition Act 2009.

70 Art. 2 Courts Act [Narodne novine 150/05, 16/07, 113/08, 153/09, 116/10, 122/10 (consolidated text), 27/11, 130/11].

71 Decision of the Agency of 30 December 2008 (Narodne novine 66/09).
} 
found to have abused its dominant position) filed several lawsuits against its 'victim': three lawsuits for different parts of the claim (outstanding invoices from various periods) are known to the author to have been filed within less than a year ${ }^{72}$. As a result, three judgments exist delivered by three different judges and two different courts related to the same parties and the same factual and legal issues, but regarding different parts of the claim. Analysing all three judgments was interesting since the rationale, arguments and issues that proved relevant to the final rulings vary considerably from one to the other. None of them failed to notice the relevance of the infringement decision of the Agency for the adjudication in the civil case, and none of them allowed the claim.

The fact that the plaintiff in the civil proceedings was found to have abused its dominant position in all three judgments was, more or less explicitly, treated as a prejudicial issue solved by the competent authority and thus seen as having a binding effect on the civil law case. Incidentally, it was not relevant for the courts that the said decision was not yet res iudicata since it has been appealed to the Administrative Court, and that the court proceedings were still pending. Nonetheless, the adjudicating commercial courts held that the decision of the Agency was binding in damages actions before them. This approach seems to follow a very extensive interpretation of Article 12 Civil Procedure Act since courts are only bound by res iudicata administrative decisions. All three courts took the findings of the Agency for granted notwithstanding the fact that the supervising administrative court had not yet ruled on the matter. However, all of the civil law judgments were primarily based on the fact that it was clear in light of relevant rules of contract law that no concordance of wills existed between the parties as regards the price increase. As a result, the claims of the plaintiff were rejected.

One of the judgments was the most clear in establishing a connection between the illegal conduct of the plaintiff as described in the antitrust decision and the claim relevant in the civil proceedings. In order to assess the validity of the claim, the court treated the issue whether the claim was founded on conduct that was deemed illegal (breach of the Competition Act) as a prejudicial question within the meaning of Article 12 of the Civil Procedure Act ${ }^{73}$. The court held that the Agency, as a competent body, adopted a decision that concerned the main issue (meritum) of the civil dispute, thereby solving the

72 Case P-664/2009, Commercial Court in Zagreb of 230/06/10; casecP-1185/2009, judgment of Commercial Court in Zagreb of 29/03/10; case P-426/08, judgment of Commercial Court in Varaždin of 25 January 2010. It is not known to the author whether Croatia Airlines filed a lawsuit against Zračna luka Zagreb for antitrust damages. It seems that the plaintiff revoked all three of its appeals against judgments of the first instance commercial courts.

73 Case P-664/2009, judgment of Commercial Court in Zagreb of 30 June 2010. 
prejudicial question determining the validity of the claim. The court accepted the findings of the Agency in their entirety, both in terms of legal assessment as well as the operative part of the decision. Most interestingly, the court explained that the antitrust decision, which was connected to the object of the civil action as regards facts and law, could not be ignored for reasons of 'consistency of public order': it held that a uniform application of the law and functional legal protection through a consistent operation of different parts of the public order system, notwithstanding which level or part thereof is considered, guarantees legal certainty. Thus the court held that there was no other option but to accept the decision of the Agency as binding as this would translate into consistent functioning of the public order system. In this light, the court accepted that behaviour found as abusive by the Agency was contra legem, and that such behaviour could not have been granted legal protection ${ }^{74}$.

One of the other two judgments shows the irritation of the court with the blatant ignorance of the plaintiff as regards the antitrust decision. As a final decision in administrative proceedings, the decision created certain obligations and its implementation represented an obligation under the Croatian legal order, in particular having in mind the significance of the Agency for the 'establishment of a legally regulated market economy'75. The court held that the plaintiff, when attempting to enforce its claim, had no legal grounds to do so since its lawsuit entirely ignored the antitrust decision. The court warned of the abuse of the procedural right to file a lawsuit (Art 9 and 10 Civil Procedure Act), and held that the plaintiff had in fact not only burdened greatly Croatian commercial courts by filing a number of baseless lawsuits, but also other competent bodies (Competition Agency, Administrative Court, misdemeanour court). This kind of behaviour was also said to might have indirectly influence the economic situation of the defendant disrupting its business and weakening its ability to focus on its core business.

It is noticeable from the third judgment that the plaintiff argued that administrative proceedings before the Agency are irrelevant for the civil law dispute at hand ${ }^{76}$. The court disagreed and held that its own ruling depended on how the Agency solved the prejudicial question (Article 12 Civil Procedure Act). The antitrust decision was thus treated by the commercial court as the foundation for the adjudication on the object of the damages

${ }^{74}$ Ibidem. The court inter alia invokes the obligation to apply provisions of the Stabilisation and Association Agreement in view of securing effet utile of Art. 70 Stabilisation and Association Agreement.

75 Case P-1185/2009, judgment of Commercial Court in Zagreb of 29 March 2010.

76 Case P-426/08, judgment of Commercial Court in Varaždin of 25 January 2010; became res iudicata after the plaintiff revoked its further appeal, see ruling of the High Commercial Court of 30 August 2011, Pž-2735/10. 
action. Rejecting the position of the plaintiff, the court stated that the plaintiff unilaterally imposed prices using its dominant position as established by the entity competent to decide on such matters under the Competition Act. The court made also a connection between substantive law (Obligations Act, and Competition Act) and procedural law (Civil Procedure Act). It was noted that the disputed price list (unilateral imposition of unfair prices) was adopted by the plaintiff contrary to basic principles of obligations law (freedom to regulate contractual relations, equality of parties, consciousness and fairness, obligation of parties to cooperate, prohibition of abuse of rights, principle of equality of obligations) ${ }^{77}$ and that the plaintiff was abusing its dominant position as established by the Agency as a prejudicial question on the basis of the Competition Act.

Moving on to a different judgment, a second instance commercial court rejected the view that an antitrust decision would have a binding effect in the given case since the plaintiff invoked a decision that declared certain vertical agreements null and void, but not actually the contract the rescission of which the plaintiff requested from the civil court ${ }^{78}$. In such circumstances, there was really no need for the court to accept the binding effect of the antitrust decision. Another interesting aspect of this case sheds some light on the division of competences between civil courts and the Agency. The adjudicating court held, and quite rightly so, that only the court itself, and not the Agency, could provide constitutive legal protection to the plaintiff by adopting a constitutive (not declaratory) judgment deciding that a voidable contract is rescinded. The court held that disputes on the existence or non-existence of contracts, as well as whether contracts were voidable, was solely within the competence of the court. Logically from this perspective, the court noted that it was in principle not bound by an antitrust decision in situations concerning the question whether a voidable contract can be rescinded. This reasoning seems in line with the Competition Act whereby the Agency, if it finds an agreement to restrict competition, declares an ex lege nullity of the agreement in the operative part of its decision ${ }^{79}$. On the other hand, as it was in the case here, the voidability of a contract does not produce legal effects ex lege but a plea for rescission must be submitted before the court which, if it finds that the contested contact was indeed voidable, adopts a constitutive decision

77 Art. 2 to 7 Obligations Act.

78 Case Pž-3220/99, judgment of High Commercial Court of 28 December 1999 which rejected the appeal as unfonded and confired the judgment of Commercial Court in Zagreb P-2736/97 of 28 October 1998.

79 Art. 8(4) Competition Act 2009. 
rescinding it $^{80}$. This kind of decision cannot be adopted by the Agency, but solely by a civil court.

\section{Case law of Croatian commercial courts - causal link and use of expert witnesses in follow-on damages actions}

Although res iudicata is not yet available, some important, albeit limited, insights into problems courts face when having to rule in follow-on antitrust damages actions derive from a judgement of the High Commercial Court quashing a ruling of a lower instance court (which rejected the claim of the plaintiff) and remanding the case for a retrial ${ }^{81}$. On the basis of an antitrust decision which found that a large pharmaceutical wholesaler abused its dominant position ${ }^{82}$, the victim (owner of a small private pharmacy) sued for damages both the wholesaler and another pharmacy chain, Ljekarne Prima Pharma from Split. The Agency found that the wholesaler applied dissimilar conditions to equivalent transactions placing some of its trading parties at a competitive disadvantage. In this case, the wholesaler was granting longer grace periods to certain pharmacies, such as the chain mentioned above, which drove the plaintiff out of business. The first instance commercial court summarily rejected the claim as regards the wholesaler, relying on the testimony of an appointed court expert for finances who found that there was no proof what caused the fall in turnover and profits of the plaintiff ${ }^{83}$. In relation to the second defendant, the court rejected the claim on the grounds that the plaintiff and the second defendant were not in any business relationship.

The second instance court found serious errors in this judgment and ordered for the lower instance court to establish during the retrial what was: the exact duration of the illegal conduct of the wholesaler, whether the plaintiff suffered damages during that time, and whether a causal link existed between the illegal behaviour and the damage ${ }^{84}$. Only after a causal link was found, could the court proceed with establishing the quantum of damages. The second instance court warned of the specifics of establishing facts in an antitrust damages case and suggested the appointment of a "professional

80 See Gorenc, Zakon o obveznim odnosima s komentarom, p. 156.

81 Case Pž-3285/04, judgment of High Commercial Courtof 27 March 2007. Case P-6986/01, judgment of Commercial Court in Zagreb of 13 January 2004. The retrial is still pending before the Commercial Court in Zagreb.

82 Decision of the Competition Agency of 29 September 2000, Ljiljana Hrnjak protiv Medika d.d. (Narodne novine 116/00).

83 Case P-6986/01, judgment of Commercial Court in Zagreb of 13 January 2004.

${ }^{84}$ Case Pž-3285/04, decision of High Commercial Court of 27 March 2007. 
institution" as an expert witness ${ }^{85}$. Furthermore, it pointed out that the lower court failed to examine evidence on the basis of which a causal link could be found between the abuse and the damage since the finance expert originally employed was also asked to determine the amount of the possible damage. In other words, the first instance court failed to understand that in this case the damages claim was based on the fact that the defendant distorted competition by abusing its dominant position. The higher court was also alarmed by the fact that the Competition Agency was not asked to inspect the court file. However, more recent judgements, as shown above in the Zračna lukav. Croatia Airlines case, although not typical follow-on actions, show a growing degree of understanding of the role and the function of the Agency in general.

\section{Access to evidence in general and legal treatment of access to corporate statements of leniency applicants}

Information asymmetry in antitrust damages cases is obviously a problem that needs to be addressed. The position of the plaintiff would be significantly improved if there were special rules that would make evidence, often concealed and held by the defendant or third parties, available to the plaintiff. However, the risk of abuses needs to be minimised. The specific question of the availability of corporate statements submitted by leniency applicants becomes highly relevant also.

US-style solutions, such as pre-trial discovery, a process in which a defendant in an antitrust damage case must disclose relevant documents, including business secrets, are not available under Croatian law ${ }^{86}$. General civil procedure rules apply here, there are no special rules to make the position of the plaintiff in antitrust damages cases more advantageous.

In Croatian civil procedure, parties are obliged to impart the facts on which their claims are based and propose evidence to establish them ${ }^{87}$. The plaintiff in a civil action for antitrust damages has two options in order to secure relevant pieces of evidence: first, it can propose to the court to obtain the file from the Agency, and second, the plaintiff could make a direct request to the Agency for access to the relevant file, explaining its legal interest as a plaintiff in civil proceedings.

85 Art. 252(3) Civil Procedure Act.

${ }^{86}$ Pre-trial discovery is not available under German law either. See U. Böge, K. Ost, 'Up and running, or is it? Private enforcement - the situation in Germany and policy perspectives' (2006) 27(4) European Competition Law Review 202.

87 Art. 7(1) Civil Procedure Act. 


\section{The right to access the file}

The right to access the file is regulated by the Competition Act 2009. However, no explicit rules on access to the file for the purpose of antitrust damages actions exist. Parties to antitrust proceedings have the right to access the file in its widest scope after they receive the statement of objections. Certain categories of documents are, nevertheless, not available for inspection even to the parties including: draft decisions of the Agency, official statements, protocols and typescripts from the sessions of the Council, internal instructions and notes on the case, communications between the Agency and the European Commission and other competition authorities and their networks, and other documents which are covered by the obligation of business secrecy in the sense of Article 53 of the Competition Act ${ }^{88}$.

The second category of entities that have the right to access the file are those who have submitted 'an initiative' to the Agency to open up antitrust proceedings ${ }^{89}$ but whose request was denied (the Agency adopted a conclusion to this effect) due to either the lack of a public interest to start proceedings ${ }^{90}$ or because conditions to open antitrust proceedings were not met ${ }^{91}$. Entities that requested the opening of antitrust proceedings are also entitled to access the file if the Agency adopts a decision finding that no antirust infringement occurred $^{92}$. The scope of the entitlement to access the file is narrower here than it is with respect to the parties to the proceedings. Covered is only the right to inspect documentation on which the conclusion or decision was founded, with the exception of documents covered by the non-disclosure rule ${ }^{93}$. Moreover, the right to access the file is not available while the proceedings

88 Art. 47 Competition Act 2009. Art. 53(2) and (3) Competition Act 2009 lists the following as confidential information: all which is defined to be a business secret by law or other regulations; all which is defined to be a business secret by the undertaking concerned if accepted as such by the Agency; all correspondence between the Agency and the European Commission and between the Agency and other international competition authorities and their networks; in particular a business secret is business information which has actual or potential economic and market value, the disclosure or use of which could result in economic advantage for other undertakings. Article 53(5) Competition Act 2009 lists inter alia the following as non-confidential information: publicly available information, historical information, annual and statistical information.

89 Art. 36(2) Competition Act 2009: any legal or natural person, professional association or economic interest group or association of undertakings, consumers association, the Government of the Republic of Croatia, central administration authorities and local and regional self-government units.

90 Art. 38(4) Competition Act 2009.

91 Art. 38(5) Competition Act 2009.

92 Art. 58(1(12) Competition Act 2009.

93 Art. 45(5) Competition Act 2009. 
are still pending. Entities that requested the opening of antitrust proceedings can access only a short version of the statement of objections before the proceedings come to a close $\mathrm{e}^{94}$.

The third category of entities that has some access to the file rights are those who do not have the status of a party to the proceedings but who find that their rights or legal interests are affected by the antitrust proceedings. They may claim, in writing, to be recognised as having the same procedural rights as those upon whose initiative the proceedings were initiated, if such legal interest is proven legitimate ${ }^{95}$. The right to access the file would include here the right to inspect the documentation on which the conclusion or decision were founded after the closure of the proceedings, as well as, upon a written request to the Agency, to obtain the short version of the statement of objections while the proceedings are still pending ${ }^{96}$.

In any case, confidential business information is always protected and thus it is not available even to the parties of the proceedings before the Agency ${ }^{97}$.

Information access rights of the plaintiff in civil damages actions are not explicitly regulated by the Competition Act. The right to access the file, either during pending antitrust proceedings or after their closure, seems to depend on the status in the proceedings before the Agency of the entity that acts as the plaintiff in the damages case. If the plaintiff is a party to the proceedings before the Agency (if the antitrust proceedings were opened against him due to an alleged antitrust infringement), such company has the right to inspect the entire file, with the exception of documents covered by the non-disclosure rule, after the delivery of the statement of objections. However, it is unlikely that an entity subject to an antitrust scrutiny would act as a plaintiff in a civil action for damages (it is far more likely to act as a defendant therein).

The Competition Act gives the explicit right to access the file only to parties in the antitrust proceedings; others (those that requested their initiation or affected by them) have only the right to inspect the 'documentation on which the conclusion or decision of the Agency are founded' and only after the closure of the proceedings. However, it is not entirely clear what would the difference be as regards the scope of the documents that can be accessed by the parties to the proceedings as opposed to 'others'. It can be presumed

94 Art. 47(6) Competition Act 2009.

95 Art. 36(3) Competition Act 2009.

96 Art. 47(6) Competition Act 2009. Against the decision on the basis of which the access to file or part thereof is denied no appeal is allowed neither may the injured party take any action. Art. 47(7) Competition Act 2009.

97 Art. 47(4) Competition Act 2009. Pursuant to Art. 59(1) Competition Act 2009 the text of the antitrust decision delivered to the parties and those who requested the proceedings will omitt confidential information. 
nevertheless, due to the difference in wording, that the right to access the file is broader than the right to inspect (only those) documents on which the decision was based. Another obvious difference is that procedural parties can inspect the file during pending proceedings while others can do so only after their closure, with the exception of a short version of the statement of objections. Importantly also, persons other than the parties cannot inspect the relevant documents if a decision finding an infringement has been adopted by the Agency - their access right is available only if the Agency refuses to open proceedings or fails to establish a violation ${ }^{98}$.

Such solution seems logical on first glance since an infringement decision would solve the prejudicial question as to the existence and extent of the antitrust violation as well as provide at least some information for the civil court to use in order to decide on the right of the plaintiff to claim damages. Nevertheless, this solution might mean that documentation which might facilitate the calculation of damages for instance, could be withheld. The question remains whether the Agency would be obliged to grant full access to the file upon request by the civil court in order to decide on damages ${ }^{99}$. The current normative set-up presupposes that it is not necessary to grant the right to access to the file for those harmed by an antitrust infringement in cases where the Agency adopts a decision finding the infringement. The decision itself is meant to provide sufficient information on which to decide civil damages actions. However, it is a factual question whether the decision of the Agency is sufficient for that purpose or whether full access to the file would be necessary.

\section{Access to corporate statements of leniency applicants}

The possibility to inspect corporate statements of leniency applicants is very limited in Croatian law ${ }^{100}$. The right to inspect them is only given to the parties in the antitrust proceedings but not before the statement of objections

98 If the Agency does not open proceedings, the plaintiff can ask the civil court to find a violation as a prejudicial issue, in particular if the Agency refused to start proceedings due to the lack of a public interest. However, if the Agency finds that there was no infringement, and its decision obtains the quality of res iudicata, the civil court would have no other option but to reject the damages claim.

${ }^{99}$ Cf. a general provision on the duty of the Agency to cooperate with judiciary in cases related to competition law infringements, Art. 66(1) Competition Act 2009.

100 The notion of a 'corporate statement' and its obligatory content are defined in Art. 5(1) and (4) Regulation of the Government of the Republic of Croatia on criteria for immunity and reduction of administrative-punitive measure, Narodne novine 129/10. For oral corporate statements see Art. 6 of the Regulation. 
is sent ${ }^{101}$. Moreover, major restrictions apply in this context: the parties and their legal representatives must declare that the accessed content will be used exclusively in the cartel proceeding in which the corporate statement was given or in the appeal against the antitrust decision before an administrative court; prohibited is also the copying of their content ${ }^{102}$. If the parties do not respect their obligations as regards the restricted use of corporate statements, the Agency may, depending on the circumstances of the case, take this into account as an aggravating circumstance when setting the fine ${ }^{103}$. There is, nevertheless, a possibility of voluntary disclosure of corporate statements by the applicant or their legal representatives. If third parties obtain access in this manner, than the obligation of restricted use is no longer valid ${ }^{104}$. It is not clear when voluntary disclosure is possible. The Commission suggests that voluntary disclosure should be precluded at least until a statement of objections is issued ${ }^{105}$. Nothing can be said about the Agency's approach to the inspection of corporate statements since it is yet to receive its first leniency application, despite the fact that relevant legislation was introduced in 2010.

The problem of the interference of the right to claim damages with the effective functioning of leniency (crucial for detecting and prosecuting cartels) has been addressed by the ECJ in the recent Pfleiderer case ${ }^{106}$. It was decided therein that EU cartel law, and in particular Regulation 1/2003, does not preclude a person who has suffered damage by an infringement of EU competition rules and who is seeking to obtain damages, from being granted access to documents relating to the leniency procedure involving the perpetrator. It is, however, for the national courts to determine on the basis of their national laws the conditions under which such access must be permitted or refused by weighing the various interests protected by EU law ${ }^{107}$.

It seems on first glance that the ECJ gave national courts substantial freedom to decide whether to grant access to corporate statements to plaintiffs in antitrust damages cases or not. Obviously however, granting access would have negative effect on the attractiveness of leniency. If the ECJ judgement is going to be interpreted in a way that jeopardises leniency programmes,

\footnotetext{
101 Ibidem Art. 7(1).

102 Ibidem Art. 7(2).

103 Ibidem Art. 7(3).

104 Ibidem Art. 7(4).

105 White Paper, p. 10.

106 Case C-360/09 Pfleiderer AG protiv Bundeskartellamt; a preliminary reference from the Amtsgericht in Bonn. More details in: C. Canenbley, T. Steinvorth, 'Effective enforcement of competition law: is there a solution to the conflict between leniency programmes and private damages actions?' (2011) 2(4) Journal of European Competition Law \& Practice, 315-326.

107 Pfleiderer, para. 23. Still, national rules may not render the implementation of EU law impossible or too difficult. Pfleiderer, para. 24.
} 
than legislative actions by the Commission are soon to be expected ${ }^{108}$. If the German NCA was willing to disclose corporate statements, and if the adjudicating German court would use the ECJ judgement to force it to do so, there is a clear risk that other NCAs or the Commission would be unwilling to exchange information with the Bundeskartellamt. This could in the end endanger the cooperation and case allocation system of the European Competition Network ${ }^{109}$.

The ECJ was so cautious in approaching this issue that it ultimately failed to formulate a clear message. Any rational court of law is likely to err on the side of caution and not allow the whole system to be jeopardised when balancing the individual interests of antitrust victims and the collective interest of maintaining the effectiveness of leniency in order to maximise the effectiveness of the public enforcement system overall ${ }^{110}$. This approach is consistent with the position of the Commission whereby corporate statements should be given adequate protection against disclosure in private damages actions regardless of whether the application for leniency is accepted, rejected or leads to no decision by the competition authority. Protection would apply where disclosure is ordered by a court, be it before or after the adoption of a decision by the authority 111 . The Commission argues at the same time that an effective private enforcement system by way of damages actions should be established to complement rather than replace or jeopardise public enforcement ${ }^{112}$.

108 For integrated proceedings as a solution for resolving conflict between the golas of public and private enforcement see: C. Canenbley, T. Steinvorth, 'Effective enforcement...', p. 324-325.

109 ECN Brief 1/2010, http://ec.europa.eu/competition/ecn/brief/01_2010/brief_01_2010_ short.pdf

110 On the basis of the ECJ judgment, the Amtsgericht in Bonn rejected Pfleiderers' claim and confirmed the decision of the Bundeskartellamt to grant partial access to the file only excluding corporate statements. See Judgment of Amtsgericht in Bonn, 18 January 2012, 51 Gs 53/09 AG Bonn, http://www.bundeskartellamt.de/wEnglisch/download/pdf/Presse/2012/2012-01-30_PR_ Pfleiderer_E.pdf. German Ministry of Economy now intends to amend the GWB in order to codify special protection of leniency documentation and to ensure its confidentiality.

111 White Paper, p. 5 and 10.

112 White Paper, p. 3. In a preliminary reference proceeding still pending before the European Court of Justice an Austrian court identified doubts as to the compatibility of Austrian antitrust law with EU law concerning third party access to file and has made a reference to the Court to clarify this, Donau Chemie and others, C-536/11. More specifically, the national court asked whether, in the light of the judgment in Pfleiderer, a national provision which only enabled access to file for third persons provided all the parties to the cartel proceedings gave their consent was precluded by European Union law. 


\section{Liability for damages for breach of competition rules under Croatian law}

\section{Legal basis and liability for damages for breach of competition rules}

The Competition Act contains no specific provisions on the right to claim antitrust damages except for the provision which allocates jurisdiction for such disputes to commercial courts ${ }^{113}$. The general prohibition clause contained in the Obligations Act which provides that every person is obliged to refrain from taking any actions that may cause damage to others is seen as the appropriate legal basis for antitrust damage claims ${ }^{114}$. The fact that there is no special provision that would establish an explicit legal basis for antitrust damage claims in Croatia is of no importance in the sense of substantive law ${ }^{115}$.

\section{Standing - indirect purchasers, passing-on defence and collective legal protection}

A general procedural norm of Croatian law provides that any natural or legal person may be a party in civil proceedings ${ }^{116}$. There are no special rules to govern legal standing in antitrust damages actions albeit the plaintiff therein would normally be a person harmed by a breach of competition rules. This could apply to a person who requested for the Agency to initiate antitrust proceedings ${ }^{117}$, a person who already acts as a party in such proceedings or a third person not involved in the proceedings before the Agency. Any natural or legal person who suffered damage by a breach of competition rules can act as a plaintiff in civil proceedings regardless of whether it is seen as an undertaking by the Competition Act. Most plaintiffs are competitors of the infringer but suppliers, buyers and consumers could also act as plaintiffs. In most cases, plaintiffs operate on a relevant market which is in a direct relationship with the defendant ${ }^{118}$.

113 Art. 69(2) Competition Act 2009. Competition Act 2003 did not contain such a provision.

114 Art. 8 Obligations Act.

115 See M. Bukovac Puvača, V. Butorac Malnar, 'Izvanugovorna odgovornost za štetu prouzročenu povredom pravila tržišnog natjecanja' (2008) 8(12) Hrvatska pravna revija 32-54, p. 34.

116 Art. 77(1) Civil Procedure Act.

117 Art. 37 Competition Act 2009. The entity who requests the initiation of proceedings is not considered a party in the proceedings. See Art. 36(2) Competition Act 2009.

118 M. Bukovac Puvača, V. Butorac Malnar, 'Izvanugovorna odgovornost....', p. 34. 
The entity that inflicted damages (hereafter: tortfeasor; defendant in civil proceedings) is usually deemed to be an undertaking by the Competition Act since only an undertaking can be found to have breached competition rules. Following entities are seen as undertakings by the Croatian Competition Act: companies, sole traders, tradesmen and craftsmen and other legal and natural persons who engage in production and/or trade in goods and/or provision of services and thereby participate in economic activity; state authorities as well as local and regional self-government units where they directly or indirectly participate in the market; any other natural or legal persons, such as associations, sports associations, institutions, copyright and related rights holders and similar which are active in the market ${ }^{119}$.

Multiple tortfeasors are jointly and severally liable for the damage caused under general tort rules ${ }^{120}$. If the defendant is a company, it is liable with all of its assets ${ }^{121}$. Similarly, a sole trader is liable personally with all of his/her assets $^{122}$. Members of general partnerships (javno trgovačko društvo) as well as general partners (komplementar) in limited partnerships (komanditno društvo) are liable personally, jointly and severally, and with all of their (personal) assets $^{123}$. Members of economic interest groupings are liable with all of their assets $^{124}$. By contrast, shareholders in a joint stock company (dioničko društvo), members of a limited liability company (društvo s ograničenom odgovornošću) and limited partners (komanditor) in a limited partnership are not liable with their personal assets. Piercing of the corporate veil is however possible if the fact that one is not liable as a company member for obligations of the company is abused ${ }^{125}$.

\subsection{Direct and indirect claimants}

Those who are in a direct relationship with the tortfeasor (competitors and other participants on the relevant market where infringement was committed, as well as direct purchasers) have a clear legal situation as regards their standing in antitrust damages cases. Since their legal interest is not questionable, their standing is also not a problem, including their capability to show a causal link between the action that caused damage and the damage that occurred ${ }^{126}$.

119 Art. 3(1) Competition Act 2009.

120 Art. 1107(1) Obligations Act.

121 Art. 9(1) Companies Act (consolidated text: Narodne novine 152/11).

122 Art. 9(2) Companies Act.

123 Art. 10(1) Companies Act.

124 Art. 592(1) Companies Act.

125 Art. 10(3) and (4) Companies Act.

126 V. Butorac Malnar, S. Petrović, 'Novo pravno uređenje tržišnog natjecanja', p. 135. Proving a causal link could be very difficult for indirect purchasers: the farther the damage 
The position of those who are in an indirect relationship with the tortfeasor is far more complex as regards proving their legal interest. Their standing as plaintiffs, proving a causal link, as well as proving the quantum of damages could all prove challenging ${ }^{127}$.

\subsection{Indirect purchasers as claimants and the passing-on defence}

The issue at hand is whether indirect purchasers may be allowed to have the standing of a plaintiff in antitrust damages cases. Damage for indirect purchasers arises when the direct purchaser passes-on the damage which was inflicted upon it by the seller (who committed the infringement). The indirect purchaser de facto suffers damage because of the seller's conduct which is in breach of competition rules despite the fact that there is no direct contact between the seller (tortfeasor) and the indirect purchaser.

EU law recognises the principle that every person has the right to be compensated for damages that arose as a consequence of an infringement of competition law. ${ }^{128}$ This is also a principle valid under general Croatian tort rules. The Commission noted in its White Paper that this principle applies to indirect purchasers also ${ }^{129}$. However, since there is no direct link between the infringer and the indirect buyer, it might be very hard for the latter to prove the passing-on of damage as well as the actual amount of damage. Indirect purchaser will thus remain uncompensated while the infringer, which has invoked the passing-on defence in the proceedings opened against him by the direct buyer, will not be found liable for damages. As a result, it will be able to keep the illegally obtained gains despite the general prohibition of unjust enrichment. To help solving this issue, the Commission proposes a measure to alleviate the burden of proof on the side of indirect purchasers: the introduction of a rebuttable presumption that the illegal overcharge was passed on to indirect purchasers in its entirety ${ }^{130}$.

\footnotetext{
was passed-on, the harder it is to prove causality. Consumers are thus in the worst positions. This issue was not addressed in the White Paper.

127 V. Butorac Malnar, S. Petrović, 'Novo pravno uređenje tržišnog natjecanja', p. 135.

128 See Manfredi, para. 61.

129 White Paper, p. 4.

130 White Paper, p. 8. Some authors suggest that this solution should be accepted in Croatian law de lege ferenda. See V. Butorac Malnar, S. Petrović, 'Novo pravno uređenje tržišnog natjecanja', p. 137.
} 


\subsection{Passing-on defence and exculpation from liability}

It is an open issue whether to allow the passing-on defence whereby the defendant in damages action (antitrust infringer) should be allowed to claim that the plaintiff passed-on the illegal overcharge to its own customers and thus suffered no harm. The Commission rightly argues that to deny this defence could result in an unjust enrichment of those who passed-on the overcharge (direct purchasers) and in the defendant being burdened in undue (multiple) compensation for its illegal actions (to the direct as well as indirect purchasers $)^{131}$. The Commission proposed therefore that the plaintiff must have the right to invoke the passing-on defence ${ }^{132}$. This is the position most legal scholars agree with.

To prohibit the passing-on defence would be contrary to European continental legal systems because damages would then be in their entirety compensated to direct purchasers, regardless of whether or not they have passed on the illegal overcharge. That would be contrary to basic principles of tort law applicable in most countries of continental Europe, including Croatia ${ }^{133}$ and in particular, contrary to the principle of unjust enrichment. As a result, the passing-on defence is often spoken of as the unjust enrichment defence ${ }^{134}$.

If the use of the passing-on defence was precluded, compensation of damages would take on a preventive and punitive function as regards the tortfeasor. That approach is not recognised by tort law of continental Europe which sees the primary goal of damages claims as compensation and restitution based on the basic rule that every person that suffered damages, including indirect purchasers, must have the right to be compensated ${ }^{135}$.

\subsection{Collective legal protection}

Collective protection of consumers encompasses: protection of collective interests of consumers and collective protection of individual interests of consumers ${ }^{136}$. Various modalities of the collective exercise of individual interests of consumers are currently being developed, despite the fact that the system

131 Confirmed in Manfredi, para. 99: EU law does not prevent national courts from acting to ensure that the protection of the rights guaranteed by EU law does not entail unjust enrichment of those who enjoy them.

132 White Paper, p. 8.

133 M. Bukovac Puvača, V. Butorac Malnar, 'Izvanugovorna odgovornost...', p. 35.

134 M. Hilgenfeld, 'Private antitrust enforcement: towards a harmonized European model or a 'patchwork' of various member states' rules' (2008) 14(2) International Trade Law Review 44.

135 M. Bukovac Puvača, V. Butorac Malnar, 'Izvanugovorna odgovornost...', p. 35.

136 Green paper - Access of consumers to justice and the settlement of consumer disputes in the single market, $\operatorname{COM}(93) 576$ final, p. 15. 
of collective exercise of individual interests is to a large extent foreign to European legal tradition ${ }^{137}$.

Croatian consumer protection law is still in an early stage of development ${ }^{138}$ covering solely the protection of collective interests of consumers. There is currently no possibility of collective protection of individual interests (in particular, by way of group actions), which is not recognised as such in Croatian civil procedural law ${ }^{139}$. In 2003, the institution of 'representative actions' (udružna tužba) was introduced by the Consumer Protection Act while the Obligations Act regulates 'popular actions' (popularna tužba; claim to eliminate danger of damage). Pursuant to the Civil Procedure Act, consumers can in principle use 'collective actions' (skupna tužba) on the basis of provisions regulating the institution of co-litigation (suparničarstvo) ${ }^{140}$.

Competition law infringements, especially cartels, are often characterised by the fact that they affect a large number of victims. As a rule, those include individual natural persons who act as purchasers of goods or services in relation to which the breach of competition law occurred. Due to the low-value damage received by each individual, such victims have no interest to individually start damages actions against the tortfeasor. The question arises therefore whether collective protection is available under Croatian law. Indeed, provisions of the Civil Procedure Act, acting as lex generalis in this context, provide an action for the protection of collective interests and rights (tužba za zaštitu kolektivnih interesa i prava). Incidentally, these provisions will not come into force until Croatia joins the EU ${ }^{141}$. However, only those organisations engaged in the protection of collective interests and rights of citizens which have been explicitly authorised by the law can file a lawsuit of that type and only if serious harm or serious distortion of collective interests and rights occurred ${ }^{142}$. Special rules must therefore be adopted in order to regulate which institutions can

137 M. Baretić, 'Individualna and kolektivna zaštita potrošača u hrvatskom pravu', [in:] V. Tomljenović, E. Čulinović Herc, V. Butorac Malnar (eds.), Republika Hrvatska na putu prema Europskom pravosudnom području: Rješenje trgovačkih and potrošačkih sporova, Pravni fakultet Sveučilišta u Rijeci, Rijeka, 2009, p. 241-285, at p. 254.

138 Ibidem, p. 285.

139 Ibidem, p. 255.

140 Co-litigation means that only those consumers which were injured may act as plaintiffs, they must all be included in the plea as plaintiffs, hence consumer association cannot start the action in their name, and each plaintiff has to prove the damage it suffered in order to be compensated. Ibid, p. 277.

141 Art. 502a-502h Civil Procedure Act [consolidated text: Narodne novine 148/11 (provisions inserted by Narodne novine 57/11)].

142 Art. 502a(1) Civil Procedure Act. Interests that can be protected in such an action are of inter alia environmental, moral, ethical, ethnic, consumer, anti-discrimination nature. Art. 502a(2) Civil Procedure Act. 
file a lawsuit for the protection of collective interests and rights related to antitrust infringements.

Actions for collective protection of interests and rights under the Civil Procedure Act only allows the plaintiff to request for the court: (a) to find that legally protected collective interests and rights of persons, whose interests the plaintiff was authorised to protect, were harmed or endangered by certain actions of the defendant ; (b) prohibit such actions; (c) order the defendant to eliminate the illegal conduct's harmful consequences and; (d) publish the ruling in the media at the defendant's cost ${ }^{143}$. The plaintiff is not allowed to request compensation however. The natural and legal persons who were actually injured can invoke, in a separate action for damages, the judgment which accepted an action for collective protection of interests and rights. In such cases, the civil court deciding on damages is bound by such earlier judgement ${ }^{144}$.

In other words, the Civil Procedure Act does not, in fact, allow actions for collective compensation of damage but only actions where a breach of collective interests and rights is established, harmful conduct declared as prohibited and harmful consequences ordered to be eliminated (abstract consumer protection $)^{145}$. In terms of antitrust damages, a collective action under the Civil Procedure Act for a breach of competition law can be filed only if special rules on the protection of collective interests and rights are adopted explicitly authorising certain organisations to file such claims. However, actions for the protection of collective interests and rights under to the Civil Procedure Act do not allow collective damage claims, since a separate action for compensation must be subsequently initiated ${ }^{146}$.

143 Art. 502b(1) Civil Procedure Act.

144 Art. 502c Civil Procedure Act.

145 M. Dika, 'Udružna tužba kao instrument apstraktne zaštite potrošača' (2003) 3(10) Hrvatska pravna revija 37-43.

146 Collective protection of consumers under Croatian law is possible under some other laws adopted before the Civil Procedure Act gained its rules on collective protection of interests and rights including: the Consumer Protection Act (Article 131-138a, Narodne novine 79/07, 125/07, 79/09, 89/09), Illicit Advertising Act (Narodne novine 43/09), and Prohibition of Discrimination Act (Narodne novine 85/2008, in force as of 1 January 2009). After the relevant provisions of the Civil Procedure Act come in force, rules based on other pieces of legislation will be applied as lex specialis in relation to Civil Procedure Act, as lex generalis.

Under Consumer Protection Act only persons authorised under special legislation may initiate actions for finding a breach of consumer rights before commercial courts. However, no decision on damages is possible within this action. A separate action for damages must be initiated by individual consumers and the ruling finding a breach of consumer rights has binding effect on the court deciding on damages (Art. 138.a Consumer Protection Act).

Collective protection of merchants from misleading and illicit comparative advertising is provided by the Illicit Advertising Act and only persons authorised by special legislation can file 
It has been argued that the system of consumer protection in Croatia has to be upgraded both in the area of individual protection and in the area of collective protection of consumer rights, and that a discussion is needed on whether the introduction of some type of group action would be advisable, taking into account possible deviations know from the US ${ }^{147}$. In this regard it is helpful to look at the views of the Commission. The introduction of two complementary mechanisms of collective redress are proposed in order to deal with the weak position of individual victims of antitrust infringements (scattered and relatively low-value damage, procedural inefficiencies if a multitude of individual actions are brought in relation to the same infringement): representative actions, which are brought by qualified entities, and opt-in collective actions, where victims can expressly decide to combine their individual claims into one single action ${ }^{148}$. Introducing such solutions in Croatia would require major modifications of its procedural law, which may encounter some resistance ${ }^{149}$.

It is clear that Croatian procedural law must be modified in order to permit actions for collective compensation of damages, its current rules do not allow for effective protection in antitrust cases. A more elaborate discussion on how these rules would have to be set up goes however outside of the scope of this paper.

a lawsuit to this effect. No decision on damages can be made by the court deciding to prohibit illegal advertising, and there is provision on the binding effect of the decision of the court finding a breach of the Illicit Advertising Act for the court decising on damages.

Under the Prohibition of Discrimination Act, a very wide circle of persons may file a 'representative action' (udružna tužba) for the protection from discrimination. It seems that this piece of legislation does not allow for a collective damages action, since it explicitly provides that only a victim of discrimination may request damages.

147 M. Baretić, 'Individualna and kolektivna zaštita...', p. 277, 284. A group (class) action is designed for compensating damage suffered by a large group and gives concrete and direct protection. Its aim is predominantly compensatory; it is brought by one or more persons in the interest of a putative group (class) which encompasses persons who suffered the same type of harm, and the plaintiff must not necessarily be part of the group in whose interest the action is brought. See Baretić, 'Individualna and kolektivna zaštita...', p. 251-252.

148 White Paper, p. 4. The Commission states that both mechanisms of collective redress should be available since they complement each other. Authorised entities might not always be interested in bringing representative actions, so victims must have an alternative mechanism at their disposal in order to get compensation.

149 M. Bukovac Puvača, V. Butorac Malnar, 'Izvanugovorna odgovornost...', p. 36. However, the choice is not between individual and collective compensation but between collective compensation and no compensation at all. See S. W. Waller, 'Towards a constructive public-private partnership to enforce competition law' (2006) 29(3) World Competition 379. 


\section{Breach of competition law as harmful act}

Two forms of breaches of the Competition Act - prohibited agreements and abuse - are recognised as harmful acts, in other words, one of the elements in proving a tort relevant for damages actions. A harmful act (̌stetna radnja) is defined as any positive or negative action of the tortfeasor which causes damage for the victim ${ }^{150}$. The object of a harmful act is not the same as the damage: while harmful acts may be exercised on persons, objects, and objects of an obligation (činidba), damage is reflected on rights and interests of the person injured by the tortfeasor ${ }^{151}$.

It has been argued that the object of a harmful act in the context of competition law is the process of competition itself since a competitive market is a state protected by competition law. After the tortfeasor caused a distortion in the competitive market structure by its illegal behaviour, damage caused by this distortion affects the rights and interests of others ${ }^{152}$. The obligation to prove that the harmful act was committed is on the plaintiff. In this context, the binding effect of antitrust decisions is highly relevant, as discussed supra.

\section{Fault requirement}

A distinction must be made between fault as a requirement to find a breach of competition law, and fault as a requirement to find liability for damages caused by that infringement. In the former case, no fault is required in order to find a prohibited agreement or abuse of a dominant position, neither in EU nor in Croatian law ${ }^{153}$. In the latter case, national tort law applies. The general rule of Croatian tort law states liability for damages on the basis of presumed fault: a person who has caused damage to another shall compensate it unless he has proven that the damage has not occurred as a result of his fault, lack of duty of care shall be presumed ${ }^{154}$. Taking into account the nature of harmful acts committed as competition law infringements and the characteristics of the tortfeasor as an undertaking, the highest possible level of care should be required ${ }^{155}$. Since

150 P. Klarić, M. Vedriš, Građansko pravo, Narodne novine, 2006, p. 586.

151 Ibidem, p. 588.

152 M. Bukovac Puvača, V. Butorac Malnar, 'Izvanugovorna odgovornost...', p. 39.

153 Abuse is an objective concept; see case 85/76 Hoffman-LaRoche ECR [1979] 461. It is visible from the text of Article 101 TFEU that agreements need to have as their aim or effect a restriction of competition, which is confirmed by EU jurisdrudence. See Commission Staff Working Paper-Annex to the Green Paper accompanying the Green Paper Damages actions for breach of the EC antitrust rules, SEC(2005) 1732, 19.12.2005, p. 31.

154 Art. 1045(1) and (2) Obligations Act.

155 M. Bukovac Puvača, V. Butorac Malnar, 'Izvanugovorna odgovornost...', p. 41. 
the burden of proof that the tortfeasor is not liable lies on that undertaking itself, and taking into account that it operates on the market in a professional capacity, it seems highly improbable for the offending undertakings to be able to rebut the presumption of its fault ${ }^{156}$.

The Commission proposes that any national fault requirements would have to be limited and, for Member States that require fault to be proven, that the infringer should be liable for damages unless it demonstrates that the violation was the result of a genuinely excusable error once the victim has shown a breach of Article 101 or 102 TFEU ${ }^{157}$. According to the Commission, the error would be excusable if a reasonable person applying a high standard of care could not have been aware of the fact that the contested conduct restricted competition ${ }^{158}$. Applying this standard of fault leaves the possibility for the infringer to be exculpated by proving that the undertaking applied a high standard of care. This would be liability on the basis of a presumed fault in which case Croatian tort law seems to be in harmony with the proposal of the Commission. Still, the standard of an excusable error would have to be interpreted in more detail and a special provision would have to be inserted into the Obligations Act to this effect ${ }^{159}$.

\section{Causal link between the infringement of competition law and the damage}

Causal link between the harmful act and the damage that was suffered by a victim is one of the requirements to finding liability for damages. The victim must prove the causal link but as a rule, there is no presumption of causality. In the context of competition law infringements, the victim/plaintiff must prove that the damage suffered was caused by the breach of competition rules committed by the defendant.

Since damage has rarely one cause, it will be necessary to find from among them the one cause which will be deemed as the relevant cause of the given damage. It is generally accepted in Croatian law that the cause must be a 'typical' cause - one which regularly causes certain harmful consequences (adequation theory) $)^{160}$.

It can be very difficult for the plaintiff in an antitrust damages action to prove such connection since an unbroken causal link between the harmful act and the damage has to be shown. It is well-known at the same time that harmful effects of an anticompetitive act can spill over various markets (even

156 Ibidem

157 White Paper, p. 6-7.

158 White Paper, p. 7.

159 M. Bukovac Puvača, V. Butorac Malnar, 'Izvanugovorna odgovornost...', p. 41, 46-47.

160 Ibidem, p. 41. 
outside the relevant market) and over various persons (competitors, direct purchasers, indirect purchasers) ${ }^{161}$.

It has been argued that courts must insist on finding a direct causal link between the harmful act and the market distortion as well as a link between the distortion and the damage suffered by a concrete victim. A causal link must connect all three elements: the harmful act, the distortion and the harm to the given victim. It is for the court to assess in each concrete case where it will draw the causality line ${ }^{162}$.

The ECJ touched upon the causality requirement only briefly in its Manfredi judgment. It noted therein that damages can certainly be claimed if there is a causal link between the damage and the agreement or practice prohibited under Article $101^{163}$. Since no supranational rules exist in this respect, it is up to the Member States to regulate this issue in accordance with the equality and effectiveness principle ${ }^{164}$.

\section{Harm as consequence of a competition law infringement - types of harm and scope of damages}

The ECJ ruled in Manfredi that injured entities must be able to seek full damages including compensation for actual loss (damnum emergens) as well as loss of profit (lucrum cessans) plus interest. Such approach is said to follow from the principle of effectiveness and the right of individuals to seek compensation for loss caused by anticompetitive conduct. ${ }^{165}$ Croatian tort law covers the following types of harm: actual loss (obična šteta), loss of profit (izmakla korist) and non-material harm, i.e. violation of privacy rights (povreda prava osobnosti) ${ }^{166}$.

Unlike most comparative legal systems, the Croatian Obligations Act explicitly provides to a legal person a fair monetary compensation for non-material damages ${ }^{167}$. It has been argued that prohibited conduct on the market, as

161 Establishing causality should be left to courts to deal with on a case to case basis.

M. Bukovac Puvača, V. Butorac Malnar, 'Izvanugovorna odgovornost...', p. 42, 46-47.

162 Ibidem, p. 42.

163 Manfredi, para. 61.

164 Manfredi, para. 64. Neither the Green Paper, nor the White Paper deal in more detail with the issue of causality.

165 Manfredi, para. 95, 100. In the absence of EU rules governing that field, it is for the domestic legal system of each Member State to set the criteria for determining the extent of the damages for harm caused provided that the principles of equivalence and effectiveness are observed. In accordance with the principle of equivalence, if it is possible to award specific damages, such as exemplary or punitive damages, in domestic actions, it must also be possible to award such damages in actions founded on EU rules. Manfredi, para. 98, 99.

166 Art. 1046 Obligations Act.

167 See Art. 1100 Obligations Act. 
a harmful act, may infringe upon personal rights of legal persons, in particular enterpreneural freedom which is protected by the Croatian Constitution [Article 49(1)]. Injured natural persons also have the right to be compensated for non-material damages suffered pursuant to Art. 19(2) Obligations Act. Hence, it has been argued that the Croatian Obligation Act offers even more avenues to compensation than mentioned in Manfredi (injury to personal rights as a type of harm, e.g. reputation) ${ }^{168}$.

The injured party has the right to be compensated both for the actual loss incurred as well as for the loss of profit ${ }^{169}$. In assessing the amount of the latter, considered should be the profit which could have reasonably been expected under normal or special circumstances, the realisation of which has been prevented by the actions or failure to act on the part of the defendant ${ }^{170}$. It has been argued that, as regards more serious breaches of competition law such as cartels, it can be expected that fair monetary compensation could also be given for the violation of privacy rights ${ }^{171}$.

As regards the scope of damages, Croatian tort law recognises the principle of full compensation: taking into account the circumstances that have occurred following the occurrence of the damage, the court shall determine the amount required in order to reverse the injured party's financial position to the state in which it would have been had the wrongful act or failure to act not occurred ${ }^{172}$.

\section{Limitation periods and the right to claim damages for infringements of competition law}

Limitation periods for compensation of damage claims are covered by the Obligations Act; there are no special rules on antitrust infringements ${ }^{173}$.

168 See M. Bukovac Puvača, V. Butorac Malnar, 'Izvanugovorna odgovornost...', p. 45-47.

169 Art. 1089(1) Obligations Act.

170 Art. 1089(3) Obligations Act.

171 M. Bukovac Puvača, V. Butorac Malnar, 'Izvanugovorna odgovornost...', p. 45.

172 Art. 1090 Obligations Act. Proportionate reduction of compensation will ensue if the injured party contributed to the occurrence of the damage or to its increase. Art. 1092(1) Obligations Act.

173 In Manfredi, the ECJ only briefly touched upon the issue of limitation periods as regards damages actions for infringements of Article 101 and 102 TFEU, and noted that in the absence of EU rules, it is on Member States to regulate this issue taking into account the principle of equality and the principle of effectiveness. Manfredi, para. 81. It held also that a national rule under which the limitation period begins to run from the day on which the agreement or concerted practice was adopted could make it practically impossible to exercise the right to seek compensation for the harm caused, particularly if that national rule imposes a short limitation period which cannot be suspended. Manfredi, para. 78 . 
Hence, general rules on limitation periods for damage claims apply. The subjective limitation period is set to three years from the time the injured party became aware of the damage or of the person causing the damage. The objective limitation period is set to five years from the moment the damage occurred $^{174}$.

These general limitation periods do not seem suitable for antitrust damages actions. Special rules should be introduced in order to facilitate antitrust damage claims. In case of continuous or repeated infringements in particular, the aforementioned limitation periods may lapse before the illegal conduct ceases to exist ${ }^{175}$. The ECJ ruled in Manfredi that, as regards continuous or repeated infringements, it can indeed happen that the limitation period expires even before the infringement is brought to an end, in which case it would be impossible for an entity that suffered harm after the expiry of the limitation period to bring a damages action ${ }^{176}$. In the case of continuous or repeated infringements, the limitation period should thus not start to be counted before the day on which the infringement cases. Moreover, the limitation period should not start to run before the victim can reasonably be expected to have knowledge of the infringement and of the harm it caused him ${ }^{177}$.

The objective limitation period set in the Croatian Obligations Act does not seem suitable for continuous or repeated infringements, since the plaintiff would be barred from claiming damages five years from the moment the damage was caused. The more appropriate solution would seem to be for the limitation period not to start to run before the day on which the infringement cases, as suggested by the European Commission.

As regards follow-on actions, limitation periods provided by the Obligations Act can prove to be too short. It is highly probable that the limitation period for initiating a damages action will lapse before the decision of the Agency or the judgement of the adjudicating administrative court becomes final (res iudicata), despite the fact that pursuant to the Competition Act court proceedings in antitrust cases are treated as urgent ${ }^{178}$. It was suggested that the most appropriate course of action for a plaintiff would be to initiate proceedings before the commercial court immediately after the antitrust

174 Art. 230(1) and (2) Obligations Act.

175 This is precisely why it was regulated in the Competition Act that the limitation period for initiating proceedings before the Agency is counted from the day when the infringement stopped. Art.71(2) Competition Act 2009. However, this provision does not deal with the issue of lapsing of limitation periods in antitrust damages actions when it comes to continuous or repeated infringements.

176 Manfredi, para. 79.

177 White Paper, p. 8.

178 See more in: V. Butorac Malnar, S. Petrović, 'Novo pravno uređenje tržišnog natjecanja', p. 139-141. 
proceedings have started since the court would be likely to stay its proceedings until the Agency adopts its decision ${ }^{179}$. The Commission proposed also that a new limitation period of at least two years should start once the infringement decision on which a follow-on claimant relies has become final (res iudicata), since there is a risk that a limitation period for claiming damages might expire while public enforcement is underway ${ }^{180}$.

\section{Conclusion}

Becoming the 28th member of the European Union, as envisaged as of 1 July 2013, will bring some significant changes to Croatia in the context of private enforcement of competition law. Still, they could have been much further reaching if the first announced but later revoked EU directive on damages claims have actually had been adopted ${ }^{181}$.

Before Croatia becomes an EU Member State, its courts must apply national legislation in the area of competition law but pursuant to Article 70 of the Stabilisation and Association Agreement criteria arising from the application of EU competition law to restrictive practices must also be applied, provided an inter-state effect exists ${ }^{182}$. After Croatia joins the EU, the acquis will become applicable in its entirety. Pursuant to Regulation 1/2003, Croatian courts and Competition Agency will both be able to apply Articles 101 and 102 TFEU $^{183}$. In addition, pursuant to Article 267 TFEU, Croatian courts will be able to use the preliminary reference mechanism.

Before accession, follow-on damages actions for breaches of Article 101 and 102 TFEU on the basis of a decision adopted by the Commission or another NCA will not be possible. Pursuant to Regulation 1/2003, decisions

179 V. Butorac Malnar, S. Petrović, 'Novo pravno uređenje tržišnog natjecanja', p. 140.

180 White Paper, p. 9. The Commission mentions also the possiblity to stop the limitation period until a competent authority adopts a decision, but it prefers a new limitation period. Croatian commentators are of the opinion that the Commision's proposal should be included in Croatian law de lege ferenda. See V. Butorac Malnar, S. Petrović, 'Novo pravno uređenje tržišnog natjecanja', p. 140.

181 Some authors welcommed the fact that the directive was revoked because of a number of unresolved issues. See J. Alfaro, T. Reher, 'The European Commission's Journey to a Directive on Damages Actions: One Step Forward - Two Steps Back!' (2011) European Antitrust Review $53-57$.

182 See Art. 70(1)(1-3) (restrictive agreements, abuse of dominat position, state aids). The Constitutional Court interpreted this provision in such way that EU law is applied as an auxiliary source of law. Decision of the Constitutional Court in case PZ Auto of 13 February 2008 (Narodne novine 25/08).

183 See Art. 5 and 6 Regulation 1/2003. 
adopted by the Commission will have binding effect in follow-on actions for Croatian courts after it EU accession, but not decisions of other NCAs ${ }^{184}$.

Croatian procedural and substantive law was not designed so as to facilitate antitrust damages claims. Now that the legislative framework for public enforcement has been perfected by the adoption of the Competition Act 2009, it is time to start discussing changes to its overall legislative framework in order to make antitrust damages actions more attractive for plaintiffs. The conflict between public and private enforcement as regards the right to access leniency documents will have to be resolved. This is not an open issue at the moment because current legislation does not seem to provide the possibility for an injured entity to get access to corporate statements or confidential business information. It is very likely that this would remain as such in the future.

Current jurisprudence of Croatian commercial courts regarding antitrust damages actions is completely underdeveloped. However, it can be expected that the rising level of public awareness of competition rules and their enforcement will soon be accompanied by an increase in the number of antitrust damages actions. Indeed, some amount of caution is required here to put things into context: large backlogs of existing cases, long duration of court proceedings, and a need for more education for judges in the area of competition law will not contribute to an immediate attractiveness of antitrust damages claims. On the other hand, the leniency programme has yet to be tested in practice, and it is assumed that the establishment of a stable public enforcement activity is a precondition for successful private enforcement of competition law.

Taking into account the discussions in the EU incited by the Commission's proposals to facilitate private enforcement in Member States, in particular the fears that its suggestions for legislative changes might negatively influence the coherence of national substantive and procedural legal systems ${ }^{185}$, one has to be cautious not to rush into novelties while the system as it is can be optimised.Current Croatian tort law is sufficiently flexible to be used in practice to accomplish the goals of competition law. The opinion has thus been expressed that no intrusive amendments will be needed here in order to facilitate antitrust damages actions ${ }^{186}$. However, especially when it comes

184 Art. 16 Regulation 1/2003.

185 J. Kortman, Ch. Swaak, 'The EC White Paper on antitrust damage actions' (2009) 30(7) European Competition Law Review 340-351, at p. 342. M. Bukovac Puvača, V. Butorac Malnar, 'Izvanugovorna odgovornost...', p. 46-47: proposals of the Commission would be very difficult to achieve without unification of tort law rules at supranational level.

186 M. Bukovac Puvača, V. Butorac Malnar, 'Izvanugovorna odgovornost...', p. 46-47. 
to collective redress, current rules of Croatian legislation seem insufficient to provide effective protection of consumers harmed by antitrust infringements.

\section{Literature}

Alfaro J., Reher T., 'The European Commission's Journey to a Directive on Damages Actions: One Step Forward - Two Steps Back!' (2011) European Antitrust Review.

Baretić M., 'Individualna i kolektivna zaštita potrošača u hrvatskom pravu' ['Individual and Collective Consumer Protection in Croatian Law'], [in:] V. Tomljenović, E. Čulinović Herc, V. Butorac Malnar (eds.), Republika Hrvatska na putu prema Europskom pravosudnom području: Rješenje trgovačkih and potrošačkih sporova [Republic Croatia on the Way Towards European Judicial Area: Solving Commercial and Consumer Cases], Pravni fakultet Sveučilišta u Rijeci, Rijeka, 2009, p. 241-285

Böge U., Ost K., 'Up and running, or is it? Private enforcement - the situation in Germany and policy perspectives' (2006) 27(4) European Competition Law Review.

Bukovac Puvača M., Butorac Malnar V., 'Izvanugovorna odgovornost za štetu prouzročenu povredom pravila tržišnog natjecanja' ['Tort Liability for Damages Caused by Infringement of Competition Rules'] (2008) 8(12) Hrvatska pravna revija.

Butorac Malnar V., Petrović S., 'Novo pravno uređenje tržišnog natjecanja' ['New Competition Rules Setup'], [in:] Zbornik 48. susreta pravnika [Collection of Papers of $48^{\text {th }}$ Legal Conference], Opatija, 12-14 May 2010, Zagreb 2010.

Butorac Malnar V., Pecotić Kaufman J., 'Ocjena koncentracija poduzetnika po kriteriju opadajućeg poslovanja u doba recesije' ['Assessment of Mergers of Undertakings and Failing Firm Defence in Times of Recession'] (2011) 61(4) Zbornik Pravnog fakulteta u Zagrebu.

Canenbley C., Steinvorth T., 'Effective enforcement of competition law: is there a solution to the conflict between leniency programmes and private damages actions?' (2011) 2(4) Journal of European Competition Law \& Practice.

Crnić I., Parnični postupak i naknada štete - Primjena propisa o parničnom postupku u parnicama za naknadu štete i iz odnosa osiguranja [Civil Litigation and Compensation of Damage - Application of Rules on Civil Procedure in Damage and Insurance Claims], Organizator 2008.

Dika M., "Prethodno pitanje" u parničnom postupku' ["Prejudicial Issue" in Civil Litigation'] (2005) 26(1) Zbornik Pravnog fakulteta Sveučilišta u Rijeci.

Dika M., 'Udružna tužba kao instrument apstraktne zaštite potrošača' ['Representative Action as an Instrument for Abstract Consumer Protection'] (2003) 3(10) Hrvatska pravna revija.

Drexl J., Conde B., Enchelmaier S., Mackenrodt M.-O., Podszun R., 'European Commission-White Paper: Damages Actions for Breach of the EC Antitrust Rules Comments by the May Planck Institute for Intellectual Property, Competition and Tax Law' (2008) 39(7) International Review of Intellectual Property and Competition Law.

Gorenc V., Zakon o obveznim odnosima s komentarom [Obligations Act with Commentary], RRiF 1998. 
Grbin I., 'Pravomoćnost odluka u parničnom postupku'['Finality of Decisions in Civil Litigation'], [in:] Godišnjak no. 9/02 - 17. savjetovanje Aktualnosti hrvatskog zakonodavstva i pravne prakse [Yearbook no. 9/02 - 17th Conference on Novelties in Croatian Legislation and Legal Practice], available at http://www.vsrh.hr/CustomPages/Static/ HRV/Files/IGrbin-Pravomocnost_odluka.pdf

Hilgenfeld M., 'Private antitrust enforcement: towards a harmonized European model or a „patchwork“ of various member states' rules' (2008) 14(2) International Trade Law Review.

Klarić P., Vedriš M., Građansko pravo [Civil Law], Narodne novine 2006.

Kortman J., Swaak Ch., 'The EC White Paper on antitrust damage actions' (2009) 30(7) European Competition Law Review.

Pavlović M., 'Značaj prejudicijelnih pitanja u parnici' ['Importance of Prejudicial Issues in Civil Litigation'] (2003) 3(7) Hrvatska pravna revija.

Triva S., Dika M., Građansko parnično procesno pravo [Civil Litigation Procedural Law], 7th ed., Narodne novine 2004.

Waller S. W., 'Towards a constructive public-private partnership to enforce competition law' (2006) 29(3) World Competition.

Wils W. P. J., 'The Relationship between Public Antitrust Enforcement and Private Actions for Damages' (2009) 32(1) World Competition. 